\title{
Anodic pretreatment of glassy carbon: impacts on structural and electrochemical characteristics of Nio nanoparticles
}

\begin{abstract}
Usually, glassy carbon electrode (GC) is used as it is as a substrate for electrochemically deposited nickel or nickel oxide ( $\mathrm{NiO}$ ) nanoparticles. In the present study, GC carbon is anodically oxidized in different media prior to electrode position of $\mathrm{NiO}_{\mathrm{x}}$ and the impacts of this pretreatment on the structural and electrochemical characteristics of $\mathrm{NiO}_{x}$ are studied. Upon anodic pretreatment of $\mathrm{GC}$ electrode in acid $\left(0.1 \mathrm{M} \mathrm{H}_{2} \mathrm{SO}_{4}, \mathrm{GC}_{\text {OX-AC }}\right)$ and in alkali $\left(0.1 \mathrm{M} \mathrm{NaOH}, \mathrm{GC}_{\mathrm{O}-\mathrm{L}}\right)$, the structural and electrochemical characterizations of nickel oxide $\left(\mathrm{NiO}_{x}\right)$ nanoparticles are highly modified. Cyclic voltammetry $(\mathrm{CV})$, scanning electron microscopy (SEM) and energy dispersive X-ray spectroscopy (EDX) are used for characterization of the electrodes. While NiOx nanoparticles deposited on $\mathrm{GC}_{\mathrm{OX}-\mathrm{AC}}$ reveal a bird-like shape, it shows semi-spherical shape when it is deposited on either $\mathrm{GC}_{\text {or }} \mathrm{GC}_{\mathrm{OX}-\mathrm{AL}}$, with smaller size on the $\mathrm{GC}_{\text {OX-AL }}$. The reversibility of the $\mathrm{Ni}(\mathrm{OH})^{2} / \mathrm{NiOOH}$ couple increases at both $\mathrm{GC}_{\mathrm{OX}-\mathrm{AC}} / \mathrm{NiO}_{\mathrm{x}}$ and $\mathrm{GC}_{\mathrm{OX}-\mathrm{AL}} / \mathrm{NiO}_{\mathrm{x}}$ compared to the untreated case, $\mathrm{GC} / \mathrm{NiOx}$. The enhancement in the electrocatalytic properties of both $\mathrm{GC}_{\text {OX-AC }} / \mathrm{NiO}_{\mathrm{x}}$ and $\mathrm{GC}_{\mathrm{OX}-\mathrm{AL}} / \mathrm{NiO}_{\mathrm{x}}$ was tested by glucose oxidation in alkaline solution. Peak current for glucose oxidation on the modified electrodes shows linear behavior according to the trend theoretically depicted by Randles-Sevcik equation for completely irreversible diffusion-controlled process. The enhancement in the catalytic activity of both $\mathrm{GC}_{\mathrm{OX}-\mathrm{AC}} / \mathrm{NiO}_{\mathrm{x}}$ and $\mathrm{GC}_{\mathrm{OX}-\mathrm{AL}} / \mathrm{NiO}_{\mathrm{x}}$ is discussed in the light of surface analysis of both electrodes compared to the untreated $\mathrm{GC}$ (i.e., $\mathrm{GC} /$ $\mathrm{NiO}_{\mathrm{x}}$.
\end{abstract}

Keywords: glassy carbo, oxidized, nickel oxide, nanoparticles, glucose, $\mathrm{AC} / \mathrm{NiO}_{x}, \mathrm{GC}_{\mathrm{ox}}$. ${ }_{\mathrm{AL}} / \mathrm{NiO}_{x}, \mathrm{H}_{2} \mathrm{SO}_{4}, \mathrm{NaOH}, 0.1 \mathrm{M} \mathrm{H}_{2} \mathrm{SO}_{4}, 0.1 \mathrm{M} \mathrm{NaOH}$
Volume 2 Issue 2 - 2017

\author{
AM Ghonim, ,',3 BE El-Anadouli,' MM Saleh',2 \\ 'Department of Chemistry, Cairo University, Egypt \\ ${ }^{2}$ Chemistry Department, King Faisal University, Saudi Arabia \\ ${ }^{3}$ Ministry of Military Production, Egypt
}

Correspondence: MM Saleh, Department of Chemistry, Cairo University, Giza, Egypt; Email mahmoudsaleh90@yahoo.com

Received: January 10, 2017 | Published: March 16,2017
Abbreviations: GC, glassy carbon electrode; $\mathrm{NiO}_{x}$, nickel oxide; $\mathrm{CV}$, cyclic voltammetry; SEM, scanning electron microscopy; EDX, energy dispersive $\mathrm{x}$-ray spectroscopy

\section{Introduction}

Despite the considerable number of articles ${ }^{1-5}$ dealing with the impacts of electrochemical pretreatment of glassy carbon (GC) electrode on the structural and electrocatalytic activity of deposited catalysts particles, the study of such impacts prior to nickel electrode position considered to be scarce. ${ }^{6}$ For instance, oxidation of GC is known to enhance its electrocatalytic properties towards many applications such as electrochemical oxidation of many organic molecules. ${ }^{7-10}$ For instance, oxidation of small organic molecules on an oxidized GC modified with Pt nanoparticles was studied. ${ }^{8-10}$ They attributed the enhancement of the electro oxidation of such molecules to the increase in the surface area and creation of $\mathrm{C}-\mathrm{O}$ functional groups on the GC substrate. While the effects of GC pretreatment by anodic oxidation on the electro oxidation of some small organic molecules have been studied, ${ }^{8-10}$ none has studied such effects on the glucose electrocatalytic oxidation albeit of equal importance. Electrochemical pretreatment of glassy carbon (GC) is performed by anodic oxidation, ${ }^{11,12}$ cathodic reduction ${ }^{13}$ or potential cycling. ${ }^{14,15}$ The above processes took place in different media, e.g., acidic or alkaline electrolytes. Pretreatment of GC by anodic oxidation has been performed in literatures with a consequent surface and structure analysis in the different solutions. ${ }^{16,17}$ The surface analysis includes the degree of roughness (surface area) and surface concentration of
C-O functional groups. In this context and here in this article, we aim to study the impacts of anodic oxidation of GC in acidic and alkaline media on the electrode position of $\mathrm{NiO}_{\mathrm{x}}$ nanoparticles. Enhancement of the electrocatalytic activity of the different modified electrodes is tested through demonstration of glucose oxidation in alkaline solution.

Nickel and nickel oxide $\left(\mathrm{NiO}_{x}\right)$ modified electrodes have received continuous and growing attention during the last decades due to their use in many technological applications including: capacitors, ${ }^{18,19}$ alkaline batteries, ${ }^{20}$ energy conversion devices ${ }^{21,22}$ and biosensors. ${ }^{23-25}$ Usually, preparation of $\mathrm{NiO}_{x}$ for electrochemical applications using different techniques is performed on ordinary untreated glassy carbon (GC) electrode. Such techniques include but not limited to:solgel preparation of powder $\mathrm{NiO}_{x}$ followed by casting ${ }^{26}$ electrode position ${ }^{27,28}$ and other techniques. ${ }^{29}$ The shape and size of the obtained $\mathrm{NiO}_{x}$ nanoparticles impose its impacts on the catalytic activity of the oxide. ${ }^{30,31}$ The electrochemical preparation, in specific, is mostly achieved on glassy carbon electrode. The latter is always pretreated by an ordinary method which is mechanical polishing followed by surface cleaning via sonication. Glucose electro oxidation using transition metal oxides, including both bulk and nanostructures based electrodes, such as $\mathrm{NiO}_{\mathrm{x}}$ is well documented. ${ }^{32-35}$ Nickel and nickel hydroxide are known of its excellent electrocatalytic performance in alkaline medium..$^{36,37}$

Combination of $\mathrm{Ni}$ and $\mathrm{NiO}$, with another element such as phosphorus (for an example) has been always aimed to increase the electro activity of electro oxidation of small organic molecules and CO tolerance. ${ }^{38-40}$ Phosphorous has abundant valence electrons and 
can affect the electronic states of the studied elements via affecting the electronic states of the main metal (Ni). ${ }^{41}$ Meanwhile, the presence of the phosphorus atoms may help to adsorb oxygen groups due to the oxophilic nature of the phosphorus. ${ }^{42}$ This can result in oxidation of the COads to carbon dioxide and hence enhance organic molecules oxidation. ${ }^{43}$ In this context and in the present work, anodic oxidation of $\mathrm{GC}$ electrode may introduce $\mathrm{C}-\mathrm{O}$ and $-\mathrm{OH}$ functional groups which can afford a high tolerance for $\mathrm{CO}$ poisoning on the $\mathrm{NiO}_{\mathrm{x}}$ surface.

In the present work, we study the impacts of anodic pretreatment of GC electrode in $\mathrm{H}_{2} \mathrm{SO}_{4}$ and $\mathrm{NaOH}$ on the surface and electrochemical and electrocatalytic characteristics of $\mathrm{NiO}_{\mathrm{x}}$ nanoparticles modified GC electrode (both untreated and pretreated). The catalyst is fabricated electrochemically and is characterized by SEM, EDX and cyclic voltammetry. To the best of our knowledge, and despite the large number of articles regarding the electrode position of nickel oxide nanoparticles on GC, the present article is a first work in studying the effects of the GC anodic pretreatment in both acid and alkaline solutions before the electrode position of important metal oxide such as $\mathrm{NiO}_{\mathrm{x}}$. The shape and size and consequently the electrocatalytic activity of the obtained $\mathrm{NiOx}$ nanoparticles are dramatically affected by the way of pretreatment of the GC electrode.

\section{Experimental}

All chemicals used in this work were of analytical grade and were purchased from Merck, Sigma Aldrich and they were used as received without further purification. All solutions were prepared using second distilled water. An ordinary cell with a three-electrode configuration was used in this study. A platinum spiral wire and an $\mathrm{Ag} / \mathrm{AgCl} / \mathrm{KCl}$ (sat.) were employed as counter and reference electrodes, respectively. Electrochemical measurements were performed using an EG\&G potentiostat (model 273A) operated with E-Chem 270 software. All potentials will be presented with respect to this reference electrode. The working electrode was a glassy carbon $(\mathrm{d}=3.0 \mathrm{~mm})$. It was cleaned by mechanical polishing with aqueous slurries of successively finer alumina powder (down to $0.06 \mu \mathrm{m}$ ) then washed thoroughly with second distilled water. Scanning electron microscope (SEM) images were taken using field emission scanning electron microscope, FESEM (FEI, QUANTA FEG 250).

GC was oxidized in $0.1 \mathrm{M}$ of $\mathrm{H}_{2} \mathrm{SO}_{4}$ (denoted as $\mathrm{GC}_{\text {OX-AC }}$ ) and in $0.1 \mathrm{M}$ of $\mathrm{NaOH}$ (denoted as $\mathrm{GC}_{\mathrm{OX}-\mathrm{AL}}$ ) at 1.0, 1.5 and $2.0 \mathrm{~V}$ for different time periods $(60,120,300 \mathrm{~s})$. The $\mathrm{GC}$ modification with $\mathrm{NiOx}$ was achieved as follows: First, the potentiostatic deposition of metallic nickel on the working electrode (i.e., $\mathrm{GC}$ or $\mathrm{G}_{\mathrm{Cox}}$ ) from an aqueous solution of $0.1 \mathrm{M}$ acetate buffer solution (ABS, $\mathrm{p}^{\mathrm{H}}=4.0$ ) containing $1 \mathrm{~m}$ $\mathrm{M} \mathrm{Ni}\left(\mathrm{NO}_{3}\right)^{2} \cdot 6 \mathrm{H}_{2} \mathrm{O}$ by applying a constant potential of $-1.0 \mathrm{~V}$. Second is the passivation of the metallic $\mathrm{Ni}$ in $0.1 \mathrm{M}$ phosphate buffer solution $\left(\mathrm{PBS}, \mathrm{p}^{\mathrm{H}}=7\right.$ ) by cycling the potential between -0.5 and $1 \mathrm{~V}$ for 10 cycles at a scan rate of $200 \mathrm{mV} / \mathrm{s}$.

Prior to each of the above steps (deposition and passivation), the electrode was rinsed in water to get rid of any contaminates from the previous step. The electrode was then activated for 20 cycles in $0.5 \mathrm{M}$ $\mathrm{NaOH}$ solution in the potential range -0.2 to $0.6 \mathrm{~V}$. The CVs were repeated twice to confirm the reproducibility of the results.

\section{Results and discussion}

\section{Surface and nanoparticles characterization}

Anodic pretreatment of GC electrode was achieved by oxidation at various anodic potentials for different time periods. Figure 1 depicts
I-t curves for anodic oxidation of $\mathrm{GC}$ electrode in $0.1 \mathrm{M} \mathrm{H}_{2} \mathrm{SO}_{4}$ (A) and $0.1 \mathrm{M} \mathrm{NaOH}(\mathrm{B})$ at constant potential of $2 \mathrm{~V}$ for $60 \mathrm{~s}$. The general features of the two curves are similar. The obtained high current at the beginning of the anodic oxidation (either in acidic or alkaline) was attributed to the charging of the double layer. The curves are similar to that obtained in literature for GC electrode. ${ }^{44}$ The current decreases to minimum values, before it increases again to reach a certain level. The current reaches its saturation higher limit once the water oxidation process is catalyzed to its possible maximum extent corresponds to the activation of the electrode process towards water oxidation. ${ }^{45}$ The current obtained under oxidation in the acid is higher than that obtained in the alkali. This may be attributed to the greater surface area (more roughness) obtained in case of acid solution compared to that in the alkaline solution (Figures 2C) (Figure 2F). This is in accordance with literatures. ${ }^{16}$

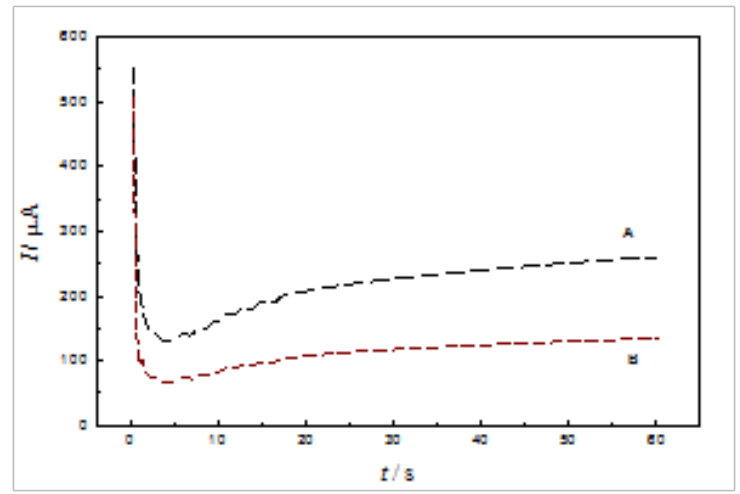

Figure I I-t relations for the oxidation of $G C$ at constant anodic potential of $2.0 \mathrm{~V}$ in $0.1 \mathrm{M} \mathrm{H}_{2} \mathrm{SO}_{4}(\mathrm{~A})$ and $0.1 \mathrm{M} \mathrm{NaOH}(\mathrm{B})$.

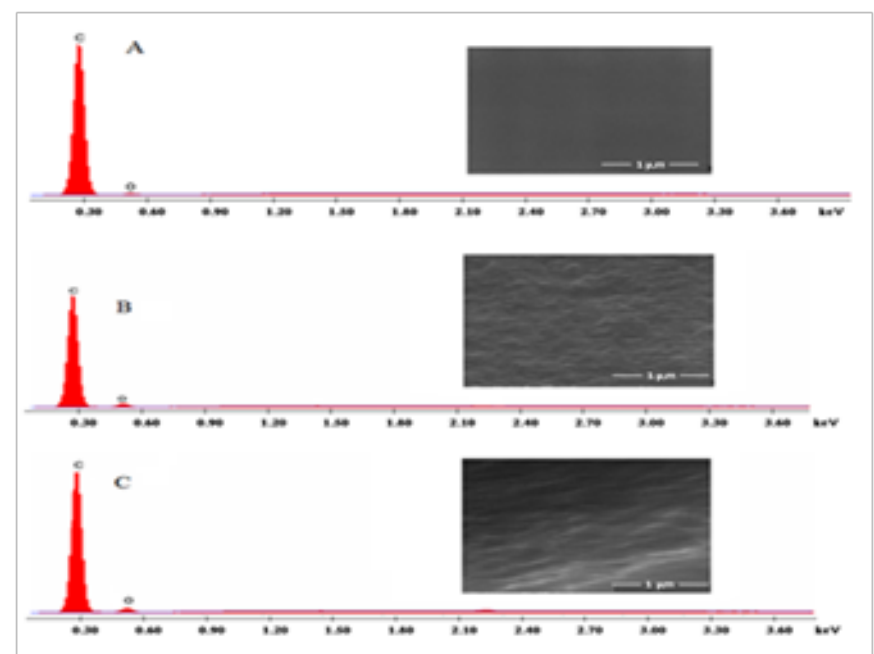

Figure 2 FE-SEM images and EDX charts of GC (A), GC $C_{O X-A C}(B)$ and $G C_{O X-A}$ (C). The $\mathrm{GC}_{\mathrm{OX}-\mathrm{AC}}$ and $\mathrm{GC}$ OX-AL were prepared by oxidation of $\mathrm{GC}$ at $2 \mathrm{~V}$ in $0.1 \mathrm{M}$ $\mathrm{H}_{2} \mathrm{SO}_{4}$ or $\mathrm{NaOH}$ for $300 \mathrm{~s}$, respectively.

Surface characterization was achieved by taking SEM images and EDX charts for the $\mathrm{GC}$ and $\mathrm{GC}_{\mathrm{ox}}$. The SEM images (Figures 2A) (Figure 2C) demonstrate the morphology and EDX charts of glassy carbon surface before (A, GC) and after oxidation of the $\mathrm{GC}$ in the acid $\left(\mathrm{B}, \mathrm{GC}_{\mathrm{OX}-\mathrm{AC}}\right)$ and in alkali $\left(\mathrm{C}, \mathrm{GC}_{\mathrm{OX}-\mathrm{AL}}\right)$, respectively at $2 \mathrm{~V}$ for 300 $\mathrm{s}$. The roughness obtained in case of $\mathrm{GC}_{\mathrm{OX}-\mathrm{AC}}$ is relatively higher than that in case of $\mathrm{GC}_{\mathrm{OX}-\mathrm{AL}}$. This may be attributed to the higher degree of penetration of the acid than of the alkali. This is in accordance with literatures. ${ }^{16}$ From the EDX charts, the estimated C/O ratio is $97 / 3$, 
90/10 and 92.3/7.7 for $\mathrm{GC}, \mathrm{GC}_{\mathrm{OX}-\mathrm{AC}}$ and $\mathrm{GC}_{\mathrm{OX}-\mathrm{AL}}$, respectively. The increase in the $\mathrm{O} \%$ upon anodic treatment of the $\mathrm{GC}$ is attributed to the increase of surface concentration of the $\mathrm{C}-\mathrm{O}$ functional groups on the $\mathrm{GC}$ surface due to surface oxidation. However, the increase in the $\mathrm{C} / \mathrm{O}$ ratio upon oxidation in the acid is higher than that obtained in the alkaline solution.

Figure 3 presents $\mathrm{SEM}$ images of the $\mathrm{GC} / \mathrm{NiO}_{\mathrm{x}}(\mathrm{A}), \mathrm{GC}_{\text {ox- } \mathrm{AC}} / \mathrm{NiO}_{\mathrm{x}}$
(B) and $\mathrm{GC}_{\mathrm{OX}-\mathrm{AL}} / \mathrm{NiO}_{\mathrm{x}}(\mathrm{C})$. These images show the morphology and particle size distribution of the $\mathrm{NiO}_{x}$ on the surface of GC before (A) and after (B, C) activation of the surface in the acid and alkali, respectively. Interestingly, the $\mathrm{NiO}_{\mathrm{x}}$ nanoparticles electrodeposited on $\mathrm{GC}_{\mathrm{OX}-\mathrm{AC}}(\mathrm{B})$ is bearing a bird-like shape with an average dimension of $(60 \times 550 \mathrm{~nm} \pm 10 \mathrm{~nm})$. The $\mathrm{NiO}_{x}$ particles obtained on $\mathrm{GC}(\mathrm{A})$ and $\mathrm{GC}_{\mathrm{OX}-\mathrm{AL}}(\mathrm{C})$ have larger average size of 130 and $80 \mathrm{~nm}( \pm 10 \mathrm{~nm})$, respectively and have semi-spherical shape.
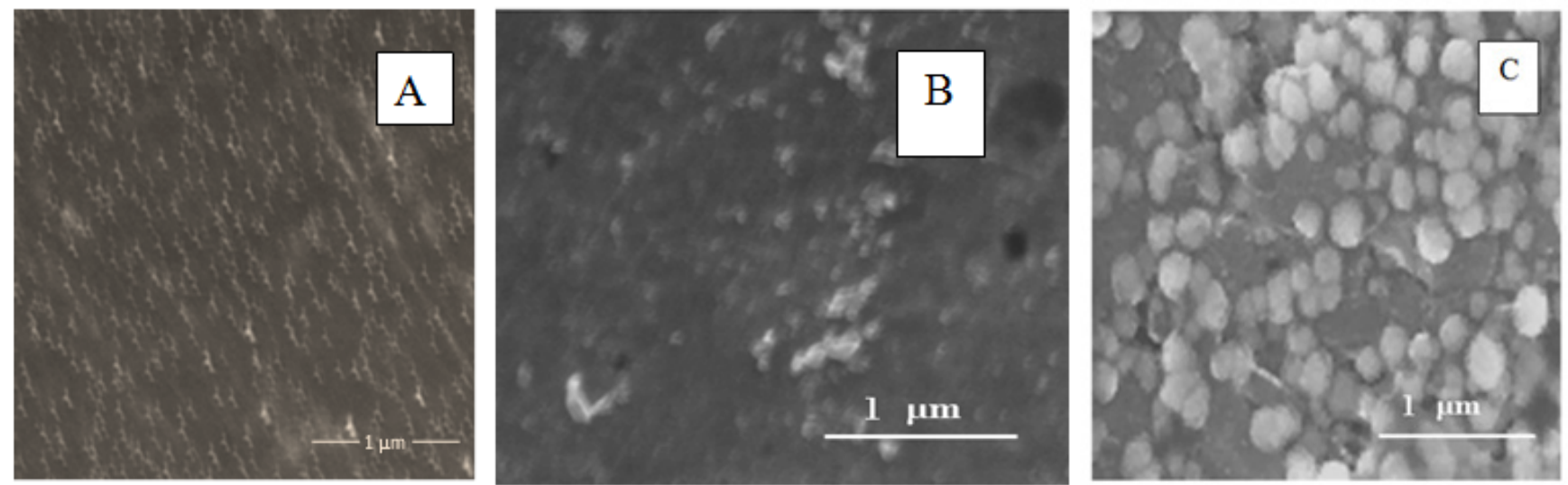

Figure $3 \mathrm{FE}-\mathrm{SEM}$ images of $\mathrm{GC} / \mathrm{NiO}$ ( $\left(\mathrm{GC}\right.$ is untreated) (A), $\mathrm{GC}_{\mathrm{Ox}-\mathrm{AC}} / \mathrm{NiO}_{x}(\mathrm{~B})$ and $\mathrm{GC}_{\mathrm{OX}-\mathrm{Al}} / \mathrm{NiO}_{x}$. Before $\mathrm{NiO}_{x}$ electro deposition, the GC was oxidized at $2 \mathrm{~V}$ for $300 \mathrm{~s}$ in $0.1 \mathrm{M} \mathrm{H}_{2} \mathrm{SO}_{4}$ (B) and $0.1 \mathrm{M} \mathrm{NaOH}(\mathrm{C})$.

\section{Impacts on the electrochemical characteristics}

Figure 4 shows histograms that demonstrate the time required for electrode position of the same amount of Ni on untreated and pretreated $\mathrm{GC}$ electrode. The Ni amount is fixed by using the same amount of electrode position charge, Q (15m C in our case). The GC electrode was pretreated by anodic oxidation at different anodic potentials, E anodic for different time periods, $t$ anodic. This amount of charge and assuming $100 \%$ columbic efficiency corresponds to a loading of $\mathrm{Ni}$ equal to $\sim 0.065 \mathrm{mgcm}^{-2}$. The figure reveals tdep decreases with the oxidation potential, $\mathrm{E}$ anodic and with the time period, $\mathrm{t}$ anodic used in the GC oxidation in acid and alkali. The modification of the GC electrode with nanoparticles of $\mathrm{NiO}_{\mathrm{x}}$ was performed as discussed in the experimental section. As discussed above, three GC electrodes were used glassy carbon without pretreatment (GC), GC after anodic oxidation at specific anodic potential for different time periods in acid $\left(\mathrm{GC}_{\mathrm{OX}-\mathrm{AC}}\right)$ or in alkali $\left(\mathrm{GC}_{\mathrm{OX}-\mathrm{AL}}\right)$.

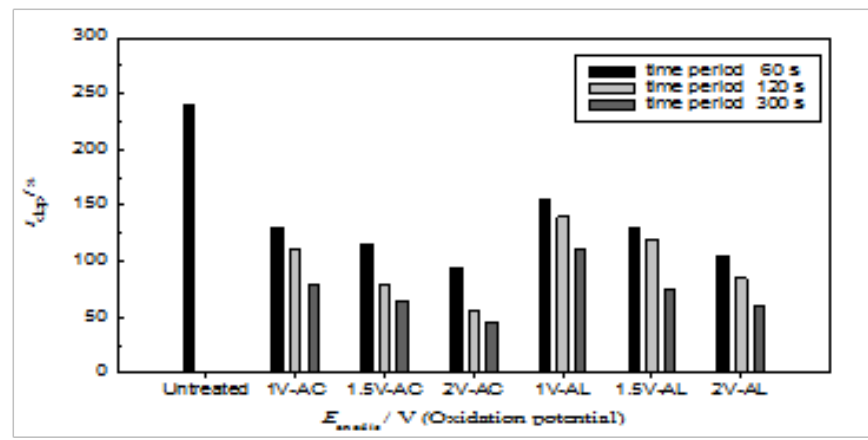

Figure 4 Time required $\left(t_{\text {dep }}\right)$ for deposition of fixed amount of $\mathrm{Ni}(Q=15 \mathrm{mC}$ in all cases) on a pretreated $\mathrm{GC}$ by anodic oxidation at different anodic potential, $E_{\text {anodic }}$ in $0.1 \mathrm{M} \mathrm{H}_{2} \mathrm{SO}_{4}\left(\mathrm{GC}_{\text {OX-AC }}\right.$ IV-AC, I.5V-AC and 2V-AC) and $0 . I \mathrm{M} \mathrm{NaOH}$ (GC $\mathrm{GX}_{\mathrm{AL}}$ IV-AL, I.5V-AL and $2 \mathrm{~V}-\mathrm{AL}$ ) for different time periods $(60,120$ and $300 \mathrm{~s})$.
The rate of an electrochemical reaction increases with the increase in the electrode surface area and hence the time required for electrode position of the same amount of $\mathrm{Ni}$ (charge passed in coulomb) decreases with the increase in the GC surface area (due to anodic pretreatment, see Figure 2). This is clearly revealed from Figure 4. We can easily note that (for an example), $45 \mathrm{~s}$ is required to pass the $15 \mathrm{~m}$ $\mathrm{C}$ at $\mathrm{GC}_{\mathrm{OX}-\mathrm{AC}}$ (anodically oxidized at $2 \mathrm{~V}$ for $300 \mathrm{~s}$ ), $60 \mathrm{~s}$ at $\mathrm{GC}_{\mathrm{OX}-\mathrm{AL}}$ (at the same oxidation conditions) and 240 s is required to pass the same amount of charge on the untreated GC electrode. This was attributed to the higher surface area and higher reactivity of the $\mathrm{GC}_{\mathrm{OX}-\mathrm{AC}}$ and $\mathrm{GC}_{\mathrm{OX}-\mathrm{AL}}$ compared to that of the untreated GC. Note that tdep (at any anodic and anodic) for the $\mathrm{GC}_{\mathrm{OX}-\mathrm{AC}}$ is lower than that of the $\mathrm{GC}_{\mathrm{OX}-\mathrm{AL}}$ which indicates higher activity of the $\mathrm{GC}_{\mathrm{OX}-\mathrm{AC}}$ compared to $\mathrm{GC}_{\mathrm{OX}-\mathrm{AL}}$. This is consistence with the conclusions driven from the SEM images and the EDX charts in Figure 2.

Figure 5 shows characteristics $\mathrm{CVs}$ for $\mathrm{GC} / \mathrm{NiO}_{\mathrm{x}}(\mathrm{A}), \mathrm{GC}_{\mathrm{OX}-\mathrm{AC}} /$ $\mathrm{NiOx}(\mathrm{B})$ and $\mathrm{GC}_{\mathrm{OX}-\mathrm{AL}} / \mathrm{NiO}_{\mathrm{x}}(\mathrm{C})$ in $0.5 \mathrm{M} \mathrm{NaOH}$ solution (blank) at different scan rates. For the $\mathrm{GC}_{\mathrm{OX}-\mathrm{AC}}$ and $\mathrm{GC}_{\mathrm{OX}-\mathrm{AL}}$, the $\mathrm{GC}$ was subjected to anodic pretreatment in $0.1 \mathrm{M} \mathrm{H}_{2} \mathrm{SO}_{4}$ or $0.1 \mathrm{M} \mathrm{NaOH}$ at $2 \mathrm{~V}$ for $300 \mathrm{~s}$ before nickel deposition. The figure reveals that the peak current for the redox couple $\left(\mathrm{Ni}(\mathrm{OH})^{2} \leftrightarrow \mathrm{NiOOH}\right)$ has the order: $\mathrm{GC} /$

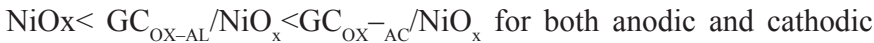
peaks. This increase in the peak current maybe attributed to the modification of the substrate surface structure which gives rise to the enhancement of the $\mathrm{NiO}_{x}$ nanoparticles activity. Also, the increase in the surface concentration of $\mathrm{C}-\mathrm{O}$ functional groups may facilitate the electron transfer for the $\mathrm{Ni}(\mathrm{OH})^{2} / \mathrm{NiOOH}$ redox couple.

The surface concentration of the active nickel sites, $\Gamma$ can be estimated using the relation $\Gamma=\mathrm{Q} / \mathrm{nF}$. Note that $\mathrm{Q}$ is the charge consumed in the $\mathrm{Ni}(\mathrm{OH})^{2} / \mathrm{NiOOH}$ process and can be estimated from the area under the $\mathrm{CV}$ curve for the above three electrodes. Taking $\mathrm{n}=1$ and $\mathrm{F}=96500 \mathrm{C} / \mathrm{mol}$, the value of was found to be $6.9,20.9$ and $17.4 \mathrm{nmolcm}^{-2}$ for $\mathrm{GC} / \mathrm{NiO}_{\mathrm{x}}, \mathrm{GC}_{\mathrm{OX}-\mathrm{AC}} / \mathrm{NiO}_{\mathrm{x}}$ and $\mathrm{GC}_{\mathrm{OX}-\mathrm{AL}} / \mathrm{NiO}_{x}$, 
respectively. Note that for the last two electrodes, the GC electrode was pretreated by oxidation at $2 \mathrm{~V}$ for $300 \mathrm{~s}$. It is noticed from the above values of $\Gamma$ that the surface concentration of $\mathrm{NiOx}$ species increases in the order $\mathrm{GC} / \mathrm{NiO}_{\mathrm{x}}<\mathrm{GC}_{\mathrm{OX}-\mathrm{AC}} / \mathrm{NiO}_{\mathrm{x}}<\mathrm{GC}_{\mathrm{OX}-\mathrm{AC}} / \mathrm{NiO}_{\mathrm{x}}$. The trend in the value of is consistent with the above recorded CVs. We may conclude that despite the equal amount of loading of NiOx nanoparticles on the electrode surface, the concentration of electrochemical active species depends on the anodic pretreatment method. That is to say, at lower particle size (either in $\mathrm{GC}_{\mathrm{OX}-\mathrm{AC}} / \mathrm{NiO}_{\mathrm{x}}$ or $\mathrm{GC}_{\mathrm{OX}-\mathrm{AL}} / \mathrm{NiO}_{\mathrm{x}}$ ), there is an increase in the corners, edges and defects on the $\mathrm{NiO}_{x}$ surface which results in higher electrochemical activity of $\mathrm{NiO}_{x}$ species. The above values of $\Gamma$ were used to estimate the loading of $\mathrm{Ni}(\mathrm{OH})^{2}$ at the different electrodes (only at the above mentioned conditions) using the relation; [loading $(\mathrm{mg} \mathrm{cm}-2)=\Gamma \times$ xolar mass of $\mathrm{Ni}(\mathrm{OH})^{2} \times 103$ ]. The estimated loading values using the above method was found to be $6.5 \times 10-4,1.95 \times 10-3$ and $1.62 \times 10-3 \mathrm{mg} \mathrm{cm}^{-2}$ forGC/NiO $\mathrm{NiC}_{\mathrm{Ox}}$ ${ }_{\mathrm{AC}} / \mathrm{NiO}_{\mathrm{x}}$ and $\mathrm{GC}_{\mathrm{OX}-\mathrm{AL}} / \mathrm{NiO}_{\mathrm{x}}$, respectively. Further, the utilization percentage, UP can be found according to the relation;

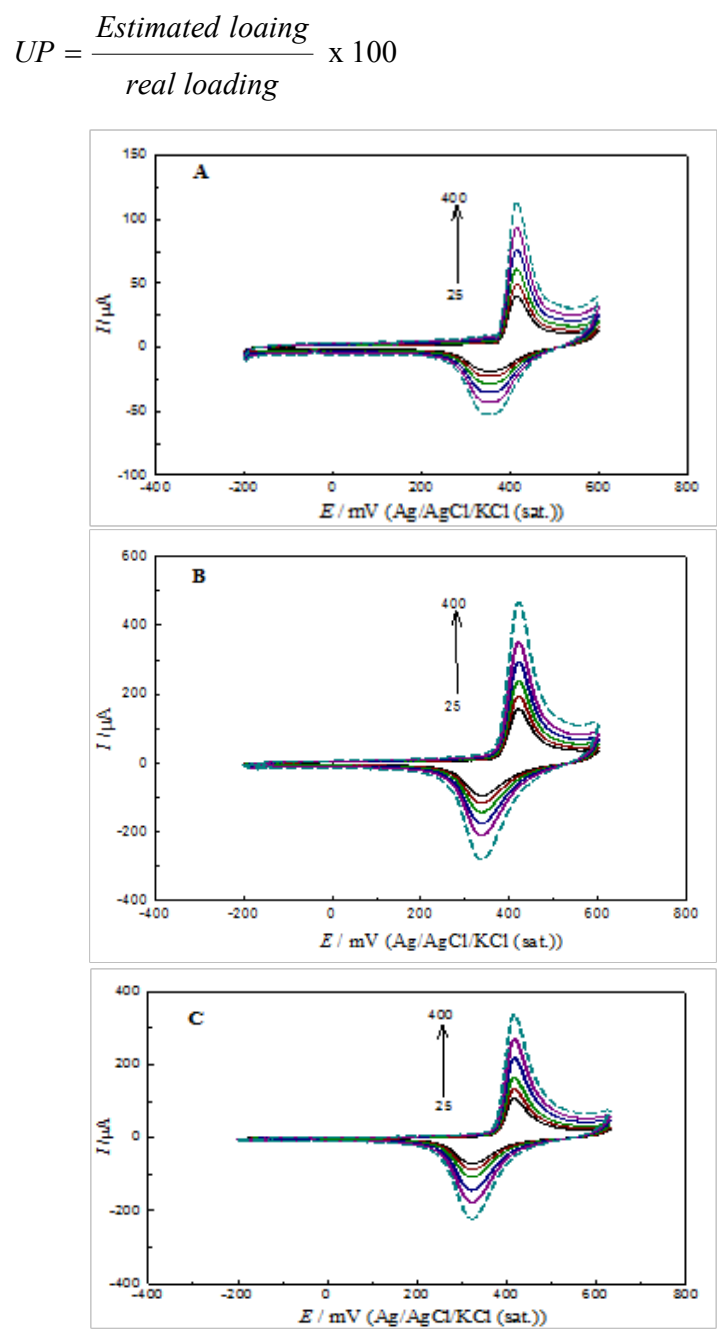

Figure $5 \mathrm{CV}$ responses for $\mathrm{GC} / \mathrm{NiO}_{x}(\mathrm{~A}), \mathrm{GC}_{\mathrm{OX}-\mathrm{AC}} / \mathrm{NiO}_{\mathrm{x}}$ (B) and $\mathrm{GC}_{\mathrm{OX}-\mathrm{AL}} /$ $\mathrm{NiO}_{x}$ (C) in $0.5 \mathrm{M} \mathrm{NaOH}$ at different scan rates in the range of 25 to $400 \mathrm{mV}$ $s^{-1}$.

The real loading as given above is $0.065 \mathrm{mg} \mathrm{cm}^{2}$. In this case, UP was estimated to be 1.0, 2.9 and $2.5 \%$ for $\mathrm{GC} / \mathrm{NiO}_{\mathrm{x}}, \mathrm{GC}_{\mathrm{OX}-\mathrm{AC}}{ }^{\prime}$ $\mathrm{NiO}_{\mathrm{x}}$ and $\mathrm{GC}_{\mathrm{OX}-\mathrm{AL}} / \mathrm{NiO}_{\mathrm{x}}$, respectively which may proof that the redox couple process has a surface nature.
The anodic and cathodic scans for the nickel hydroxide modified electrode are known to produce various phases of the hydroxide namely, $\beta-\mathrm{Ni}(\mathrm{OH})^{2}, \alpha-\mathrm{Ni}(\mathrm{OH})^{2}, \beta-\mathrm{NiOOH}$, and $\gamma-\mathrm{NiOOH} .{ }^{40}$ It is well known that the formation of $\gamma-\mathrm{NiOOH}$ phase is associated with swelling of the nickel film and consequently, micro cracks and disintegrates may be formed. Therefore, $\beta-\mathrm{NiOOH}$ phase is expected to be a better electro active material for high electrochemical performance in alkaline solution. ${ }^{46}$ There is also a possibility of preferential formation of $\beta-\mathrm{NiOOH}$ at the $\mathrm{GCO}_{\mathrm{x}}$ but not on GC. The $\mathrm{Ni}(\mathrm{II}) / \mathrm{Ni}(\mathrm{III})$ conversion occur via a mechanism in which $\beta-\mathrm{NiOOH}$ is likely formed by solvent mechanism in which $\gamma-\mathrm{NiOOH}$ is formed through the diffusion of (Equation 1). ${ }^{47,48}$

$$
\mathrm{Ni}(\mathrm{OH})_{2}+\mathrm{OH}^{-} \leftrightarrow \mathrm{NiOOH}+\mathrm{H}_{2} \mathrm{O}+\mathrm{e}^{-}
$$

In the next section we are going to study the impacts of the above findings on the electrocatalytic properties of NiOx towards glucose oxidation in alkaline solution. Similar CVs to that shown in Figures $5 \mathrm{~A} \& 5 \mathrm{C}$ were collected for $\mathrm{GC}_{\mathrm{OX}-\mathrm{AC}} / \mathrm{NiO}_{\mathrm{x}}$ and $\mathrm{GC}_{\mathrm{OX}-\mathrm{AL}} / \mathrm{NiO}_{\mathrm{x}}$ where the GC was anodically pretreated by oxidation at different anodic and anodic prior to $\mathrm{NiO}_{\mathrm{x}}$ deposition. Analysis of the above collected CVs was performed to extract important electrochemical parameters. Table 1 lists such parameters. These include; the anodic and cathodic peak current of the $\mathrm{Ni}(\mathrm{OH})^{2} / \mathrm{NiOOH}$ redox couple, $\mathrm{I}_{\mathrm{Pa}}$ and $\mathrm{I}_{\mathrm{Pc}}$, respectively, ratio of the peak currents $\left(\mathrm{I}_{\mathrm{Pc}_{\mathrm{c}}} / \mathrm{I}_{\mathrm{Pa}}\right)$ and the surface concentration of $\mathrm{Ni}$ active sites, As E anodic and/or t anodic increases, the peak current (especially $\mathrm{I}_{\mathrm{pa}}$ ) increases and the ratio $\mathrm{I}_{\mathrm{pc}} / \mathrm{I}_{\mathrm{Pa}}$ increases and becomes more closer to unity compared to those of the $\mathrm{GC} / \mathrm{NiO}$. The above results imply that the reactivity and reversibility of the $\mathrm{Ni}(\mathrm{OH})^{2} /$ $\mathrm{NiOOH}$ redox couple increases upon anodic pretreatment of the GC. Also, the surface concentration, increases with anodic and/or anodic pointing to the increase in the concentration of the Ni active species in the matrix.

Further analysis of the data in Figures 5A \& Figure 5C was done by plotting the peak current of both the anodic and cathodic scans with the square root of the scan rate, $v 0.5$. Figure 6 depicts the Ip- $v 0.5$ plots for the three electrodes. The plots reveal a straight line which is assigned for a surface confined process. The lines do not pass though the origin maybe due to a non-complete reversibility of the process. Note that the peak potential separation, $\Delta \mathrm{E}_{\mathrm{p}}=\mathrm{E}_{\mathrm{pc}}-\mathrm{E}_{\mathrm{pa}}$ in the three electrodes is comparable. The average $\Delta \mathrm{E}_{\mathrm{p}}$ is $75 \mathrm{mV}$ among the three electrodes.

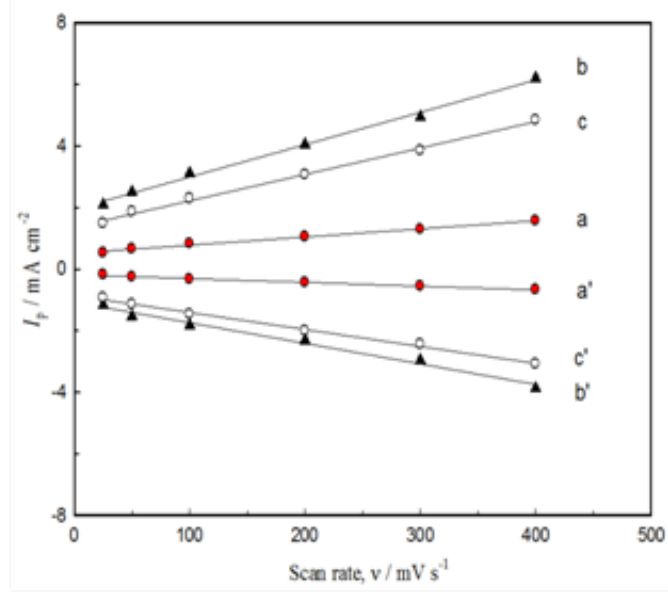

Figure 6 Effect of scan rate on the anodic peak current of the redox $\mathrm{Ni}(\mathrm{OH})_{2}$ I $\mathrm{NiOOH})$ for $\mathrm{GC} / \mathrm{NiO}_{\mathrm{x}}\left(\mathrm{GC}\right.$ is untreated) (a, a'), $\mathrm{GC}_{\mathrm{OX}-\mathrm{AC}} / \mathrm{NiO}_{x}\left(\mathrm{~b}, \mathrm{~b}^{\prime}\right)$ and $\mathrm{GC}_{\text {Ox-AL }} / \mathrm{NiO}_{x}\left(\mathrm{c}, \mathrm{c}^{\prime}\right)$. Before $\mathrm{NiO}_{x}$ electrodeposition, the $\mathrm{GC}$ was oxidized at 2 $V$ for $300 \mathrm{~s}$ in $0.1 \mathrm{M} \mathrm{H}_{2} \mathrm{SO}_{4}$ (B) and $0.1 \mathrm{M} \mathrm{NaOH}(\mathrm{C})$. 
Table I Electrochemical parameters extracted from $\mathrm{CVs}$ for $\mathrm{GC} / \mathrm{NiO}_{x}, \mathrm{GC}_{\mathrm{Ox}-\mathrm{AC}} / \mathrm{NiO}_{\mathrm{x}}$ and $\mathrm{GC}_{\mathrm{Ox}-\mathrm{AL}} / \mathrm{NiO}$, electrodes in $0.5 \mathrm{M} \mathrm{NaOH}$ (blank). The parameters are: anodic peak current, $I_{\mathrm{pa}}$, cathodic peak current, $I_{\mathrm{pc}}$, the ratio $\left(I_{\mathrm{pc}} / I_{\mathrm{pa}}\right)$ and the surface concentration of Ni sites, $\Gamma$.The GC was pretreated in different solutions at different anodic potentials, $E_{\text {anodic }}$ and different time periods of anodic oxidation, $t_{\text {anodic }}$

\begin{tabular}{|c|c|c|c|c|c|c|c|c|c|}
\hline \multirow{2}{*}{$t_{\text {anodic }} / s$} & \multirow{2}{*}{$E_{\text {anodic }} / \mathbf{V}$} & \multicolumn{4}{|c|}{$\mathrm{GC}_{\mathrm{ox}-\mathrm{AC}} / \mathrm{NiO}{ }_{x}$} & \multicolumn{4}{|c|}{$\mathrm{GC}_{\mathrm{ox}-\mathrm{AL}} / \mathrm{NiO}_{\mathrm{x}}$} \\
\hline & & $I_{p a} / \mu \mathrm{A}$ & $I_{p c} / \mu \mathrm{A}$ & Ratio $I_{p c} / I_{p a}$ & $\Gamma / \mathrm{nmol} \mathrm{cm}^{-2}$ & $I_{p a} / \mu \mathrm{A}$ & $I_{p c} / \mu \mathrm{A}$ & Ratio $I_{p c} I_{p a}$ & $\Gamma / \mathrm{nmol} \mathrm{cm}^{-2}$ \\
\hline \multirow[t]{2}{*}{0} & Untreated & 47 & 22 & 0.46 & 6.9 & 47 & 22 & 0.46 & 6.9 \\
\hline & I & 71 & 33 & 0.473 & 9.6 & 53 & 34 & 0.63 & 9.1 \\
\hline \multirow[t]{3}{*}{60} & 1.5 & 78 & 42 & 0.523 & 10.9 & 77 & 49 & 0.646 & 10.4 \\
\hline & 2 & 103 & 50 & 0.484 & 12.2 & 86 & 50 & 0.586 & 10.2 \\
\hline & I & 84 & 40 & 0.473 & 9.7 & 79 & 48 & 0.6 & 13.7 \\
\hline \multirow[t]{3}{*}{120} & 1.5 & 103 & 78 & 0.751 & 15.5 & 95 & 49 & 0.52 & 14.6 \\
\hline & 2 & 130 & 79 & 0.606 & 19.7 & 105 & 60 & 0.577 & 12.4 \\
\hline & 1 & 103 & 62 & 0.598 & 16.7 & 106 & 68 & 0.638 & 15.1 \\
\hline \multirow[t]{2}{*}{300} & 1.5 & 144 & 109 & 0.758 & 19.7 & 109 & 72 & 0.656 & 14.4 \\
\hline & 2 & 192 & 115 & 0.6 & 20.9 & 133 & 87 & 0.654 & 17.4 \\
\hline
\end{tabular}

\section{Electrocatalytic activity}

Figure 7 shows $\mathrm{CV}$ responses for glucose oxidation at the different electrodes from $0.5 \mathrm{M} \mathrm{NaOH}$ containing $20 \mathrm{mM}$ glucose solutions at scan rate of $100 \mathrm{mVs}^{-1}$. The electrodes are; a) $\left.\left.\mathrm{GC}, \mathrm{b}\right) \mathrm{GC}_{\mathrm{OX}-\mathrm{AC}}\right) \mathrm{GC}_{\mathrm{OX}-\mathrm{AL}}$, d) $\mathrm{GC} / \mathrm{NiO}_{x}$, e) $\left.\mathrm{GC}_{\mathrm{OX}-\mathrm{AC}} / \mathrm{NiO}_{\mathrm{xf}}\right) \mathrm{GC}_{\mathrm{OX}-\mathrm{AL}} / \mathrm{NiO}_{\mathrm{x}}$. The last two electrodes (curves e and f) were prepared by anodic pretreatment of GC electrode at $2 \mathrm{~V}$ for $300 \mathrm{~s}$ in $0.1 \mathrm{M} \mathrm{H}_{2} \mathrm{SO}_{4}$ and $0.1 \mathrm{M} \mathrm{NaOH}$, respectively. The first three electrodes, ((a) GC, b) $\mathrm{GC}_{\text {OX-AC }}$, and c) $\mathrm{GC}_{\text {OX-AL }}$ ) do not show any significant catalytic action towards glucose oxidation. The figure demonstrates that both $\mathrm{GC}_{\text {OX-AC }} / \mathrm{NiO}_{x}$ (curve e) and $\mathrm{GC}_{\text {OX-AL }}$ ' $\mathrm{NiO}_{x}$ (curve f) show dramatic increases in the peak current of glucose oxidation compared to $\mathrm{GC} / \mathrm{NiO}_{\mathrm{x}}$ (curve d). A negative shift in the onset potential, Eon set of glucose oxidation is obtained in case of either $\mathrm{GC}_{\text {OX-AL }} / \mathrm{NiO}_{\mathrm{x}}$ and $\mathrm{GC}_{\mathrm{OX}-\mathrm{AL}} / \mathrm{NiO}_{\mathrm{x}}$. For instance, Eon set of glucose oxidation is $0.30,0.25$ and $0.18 \mathrm{~V}$ for $\mathrm{GC} / \mathrm{NiO}_{\mathrm{x}}, \mathrm{GC}_{\mathrm{OX}-\mathrm{AC}} / \mathrm{NiO}_{\mathrm{x}}$ and $\mathrm{GC}_{\text {OX-AL }} / \mathrm{NiO}_{x}$, respectively. It points to the faster kinetics of glucose oxidation on the $\mathrm{GC}_{\text {OX-AL }} / \mathrm{NiO}_{x}$ compared to $\mathrm{GC}_{\text {OX-AC }} / \mathrm{NiO}_{x}$. However, since surface concentration, $\Gamma$ nickel species in case of $\mathrm{GC}_{\mathrm{OX}-\mathrm{AC}} / \mathrm{NiO}_{\mathrm{x}}$ is higher than that estimated for $\mathrm{GC}_{\mathrm{OX}-\mathrm{AL}} / \mathrm{NiO}_{\mathrm{x}}$, a factor that give rise to higher concentration of $\mathrm{NiOOH}$ species which responsible for glucose oxidation according to the following mechanism.

$$
\begin{aligned}
& \mathrm{NiOOH}+\text { glucose } \rightarrow \text { intermdiate }+\mathrm{Ni}(\mathrm{OH})_{2} \\
& \mathrm{NiOOH}+\text { intermdiate } \rightarrow \text { products }+\mathrm{Ni}(\mathrm{OH})_{2}
\end{aligned}
$$

That is to say, while anodic oxidation of GC in acidic solution results in an increase in the peak current of glucose oxidation, it affects both peak current and Eon set upon anodic treatment in alkaline solution. The negative shift in Eon set points to the easiness and facilitated oxidation of glucose on $\mathrm{GC}_{\mathrm{OX}-\mathrm{AL}} / \mathrm{NiO}_{\mathrm{x}}$. In the other hand the increase in the peak current may be attributed to the GC surface modification and the increase in surface area of the GC.

Similar $\mathrm{CV}_{\mathrm{s}}$ to that obtained in Figure 7 were measured for glucose oxidation on the different electrodes at different conditions of GC anodic oxidation. The figures were analyzed and important electrochemical parameters are extracted. Table 2 lists the values of peak current, $I_{p}$ and peak potential, $E_{p}$ of glucose oxidation at the different electrodes and conditions (different anodic and anodic of GC oxidation). The results point to the enhancement of the glucose electro oxidation upon anodic oxidation of GC in acidic and alkaline solutions. The increase in anodic and/or anodic results in an increase in the peak current of glucose oxidation. The increase in Ip for $\mathrm{GC}_{\mathrm{OX}}$. ${ }_{\mathrm{AC}} / \mathrm{NiO}_{\mathrm{x}}$ is more pronounced than that for $\mathrm{GC}_{\mathrm{OX}-\mathrm{AL}} / \mathrm{NiO}_{\mathrm{x}}$. However, $\mathrm{GC}_{\text {OX-AL }} / \mathrm{NiO}_{\mathrm{x}}$ shows a negative shift in the peak potential for glucose oxidation. This may be attributed to the impacts of the different shape and size of the $\mathrm{NiO}_{\mathrm{x}}$ nanoparticles as discussed in Figures 2 \& Figure 3 (Table 1).

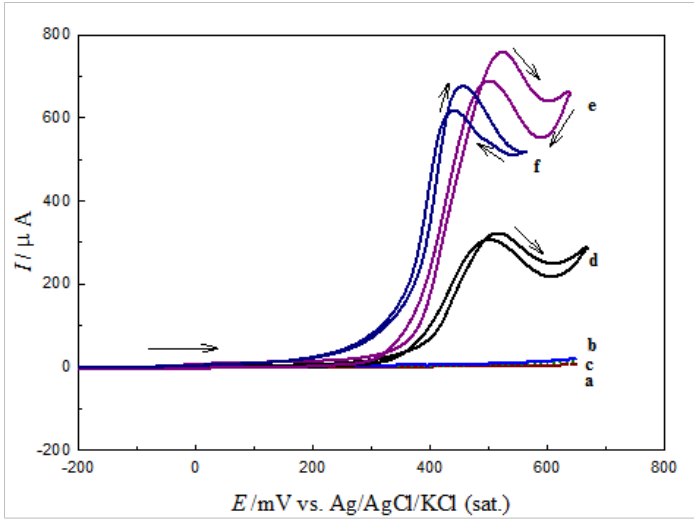

Figure $7 \mathrm{CV}$ responses for glucose oxidation on different electrodes in 0.5 $\mathrm{M} \mathrm{NaOH}$ containing of $20 \mathrm{mM}$ of glucose solution using scan rate of $100 \mathrm{mV}$ $\mathrm{s}^{-1}$. Electrodes are: GC (A), GC OX-AC $_{\text {(B), }} \mathrm{GC}_{\text {OX-AL }}(\mathrm{C}), \mathrm{GC} / \mathrm{NiO}_{x}(\mathrm{D}), \mathrm{GC}_{\text {OX-AC }}$ $\mathrm{NiO}_{x}(\mathrm{E})$ and $\mathrm{GC}_{\mathrm{OX}-\mathrm{AL}} / \mathrm{NiO}$

The enhancement of glucose oxidation cannot be correlated to a possible different loadings of the $\mathrm{NiO}_{x}$ since fixed amount of charge $\left(15 \mathrm{~m}_{\mathrm{C}}\right)$ is passed during the $\mathrm{Ni}$ electrode position on either $\mathrm{GC}$ or $\mathrm{GC}_{\mathrm{OX}-\mathrm{AC}}$ or $\mathrm{GC}_{\mathrm{OX}-\mathrm{AL}}$ at any conditions (see Figure 4) (see also discussion in the previous section). That is to say, the enhancement in the electrocatalytic activity of $\mathrm{GC}_{\mathrm{OX}-\mathrm{AC}} / \mathrm{NiO}_{\mathrm{x}}$ or $\mathrm{GC}_{\mathrm{OX}-\mathrm{AL}} / \mathrm{NiO}_{\mathrm{x}}$ towards glucose oxidation was not attributed to different loadings of $\mathrm{NiO}_{x}$ but rather to the modification of the GC surface by anodic oxidation and the consequent changes in the shape and size of the $\mathrm{NiO}_{x}$ nanoparticles. It is concluded that the enhancement is attributed to the increase in the substrate (GC) surface area which gives rise to a better exposure of the $\mathrm{NiO}_{\mathrm{x}}$ nanoparticles to glucose oxidation. As revealed from the SEM images in Figure 3, the size of $\mathrm{NiO}_{\mathrm{x}}$ nanoparticles on $\mathrm{GC}_{\mathrm{Ox}}$ is lower 
than that deposited on the untreated GC. The decrease in the size of the $\mathrm{NiO}_{\mathrm{x}}$ nanoparticles is accompanied by an increase in the available corners, edges and defects on the $\mathrm{NiO}_{\mathrm{x}}$ surfaces which facilitated and hence lead to an increase in the peak current of glucose oxidation. Also, a possible synergism between $\mathrm{NiO}_{\mathrm{x}}$ and the newly generated $\mathrm{C}-\mathrm{O}$ functional groups exist. Further possibility is the preferable deposition of active $\beta-\mathrm{NiOOH}$ rather than less active $\gamma-\mathrm{NiOOH}$.

An attempt to correlate the modification that took place on the electrochemical characteristics of the $\mathrm{Ni}(\mathrm{OH})^{2} / \mathrm{NiOOH}$ redox couple (Table 1) with the enhancement in glucose oxidation (Table 2) can derive us to the following remarks. The enhancement in the glucose oxidation is affected by the increase in the peak current of the $\mathrm{Ni}^{2+}$ / $\mathrm{Ni}^{3+}$ couple and the surface concentration of the active $\mathrm{Ni}$ species. It rather and to some extent does not depend on the ratio $\left(I_{P_{c}} / I_{p a}\right)$. That is to say, the enhancement depends mainly on the amount of the active $\mathrm{Ni}$ species and to little extent on its reversibility. The disappearance of the cathodic peak of the conversion $\mathrm{NiOOH} \rightarrow \mathrm{Ni}(\mathrm{OH})^{2}$ from the cathodic scan (Figure 7) is an evidence of the role of the $\mathrm{NiOOH}$ concentration on the oxidation of glucose by what is well known electrocatalytic mechanism.

Table 2 Electrochemical parameters extracted from LSV for glucose oxidation on $\mathrm{GC} / \mathrm{NiO}, \mathrm{GC}_{\mathrm{OX}-\mathrm{AC}} / \mathrm{NiO}_{\mathrm{x}}$ and $\mathrm{GC}_{\mathrm{OX}-\mathrm{AL}} / \mathrm{NiO}$, electrodes in $0.5 \mathrm{M} \mathrm{NaOH}$ containing $20 \mathrm{mM}$ glucose. These are: peak current, $I_{\mathrm{p}}$, peak potential, $E_{\mathrm{p}}$ and onset potential, $E_{\text {onset }}$ of glucose oxidation. $G C$ was oxidized at different anodic potential, $E_{\text {anodic }}$ and for different time period, $t_{\text {anodic }}$

\begin{tabular}{|c|c|c|c|c|c|}
\hline$t_{\text {anodic }} / \mathrm{s}$ & $E_{\text {anodic }} / \mathbf{V}$ & $I_{p} / \mu \mathrm{A}$ & & $E_{p} / \mathbf{V}$ & \\
\hline 0 & $\mathrm{GC} / \mathrm{NiO}_{x}$ Untreated & 325 & 325 & 493 & 493 \\
\hline \multicolumn{2}{|c|}{ Modified Electrodes } & $\mathrm{GC}_{\mathrm{ox}-\mathrm{Ac}} / \mathrm{NiO} \mathrm{x}_{\mathrm{x}}$ & $\mathrm{GC}_{\text {ox-AL }} / \mathrm{NiO}_{\mathrm{x}}$ & $\mathrm{GC}_{\mathrm{ox}-\mathrm{AC}} / \mathrm{NiO} \mathrm{x}_{\mathrm{x}}$ & $\mathrm{GC}_{\mathrm{ox}-\mathrm{AL}} / \mathrm{NiO}{ }_{x}$ \\
\hline \multirow{3}{*}{60} & 1 & 410 & 390 & 537 & 498 \\
\hline & 1.5 & 460 & 405 & 532 & 497 \\
\hline & 2 & 485 & 450 & 526 & 458 \\
\hline \multirow{3}{*}{120} & 1 & 455 & 430 & 537 & 493 \\
\hline & 1.5 & 560 & 510 & 526 & 492 \\
\hline & 2 & 635 & 585 & 531 & 470 \\
\hline \multirow{3}{*}{300} & 1 & 485 & 456 & 520 & 485 \\
\hline & 1.5 & 634 & 585 & 526 & 475 \\
\hline & 2 & 765 & 680 & 534 & 456 \\
\hline
\end{tabular}

Figure 8 shows LSV responses of $\mathrm{GC}_{\mathrm{OX}-\mathrm{AC}}$ in $0.5 \mathrm{M} \mathrm{NaOH}$ containing $20 \mathrm{~mm}$ glucose at scan range from 25 to $400 \mathrm{mVs}^{-1}$. The LSV reveal an increase of the peak current of glucose oxidation with a notable positive shift in the peak potential with the scan rate. The disappearance of the reversed scan (cathodic scan) and the positive shift is a characteristic of irreversible voltammetric behavior. The peak current obtained for glucose oxidation after subtracting the background (glucose-free LSV) is proportional to the square root of the scan rate (Figure 9), indicating a typical behavior for a mass transfer controlled reaction. The peak current, $I_{p}$ of diffusioncontrolled totally irreversible process can be given by Randles-Sevcik equation (Equation 4). ${ }^{49}$

$$
I_{\mathrm{p}}=2.99 \times 10^{5} n\left(\alpha n_{a}\right)^{0.5} A C(D v)^{0.5}
$$

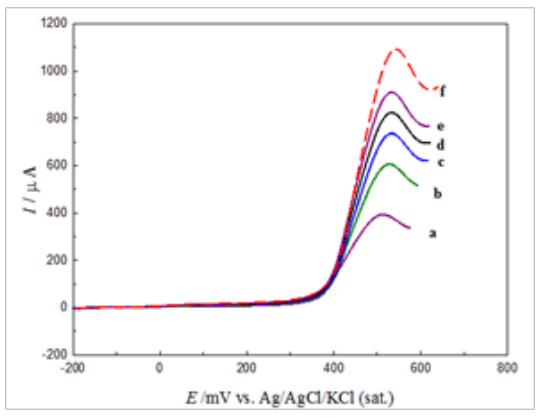

Figure $8 \mathrm{LSV}$ responses for glucose oxidation on $\mathrm{GC}_{\text {ox- } \mathrm{AC}} / \mathrm{NiO}_{\mathrm{x}}$ from $0.5 \mathrm{M}$ $\mathrm{NaOH}$ containing $20 \mathrm{mM}$ glucose. Potential scan rate: (A) 25, (B) 50, (C) 100, (D) 200, (E) 300, (F) $400 \mathrm{mVs}^{-1}$. where $I_{p}$ is the peak current of glucose oxidation, A, n is the total number of electrons $(\mathrm{n}=2), \alpha$ is the charge transfer coefficient $\left(\alpha=0.59^{50}\right)$, na is the number of electrons in the rate determining step, $\mathrm{na}=1, \mathrm{~A}$ is the surface area of the working electrode $\left(\mathrm{A}=0.07 \mathrm{~cm}^{2}\right), \mathrm{D}$ is the diffusion coefficient of glucose $\left(\mathrm{D}=6.67 \times 10^{-6} \mathrm{~cm}^{2} \mathrm{~s}^{-151}\right), \mathrm{C}$ is the bulk concentration of the glucose and $\mathrm{v}$ is the scan rate $\left(\mathrm{V} \mathrm{s}^{-1}\right)$. The theoretical plot based on Randles-Sevcik equation is given in Figure 9 (dashed line). It can be concluded that the calculated Randles-Sevcik plot and the experimental data are in qualitative agreement. This indicates a diffusion controlled process.

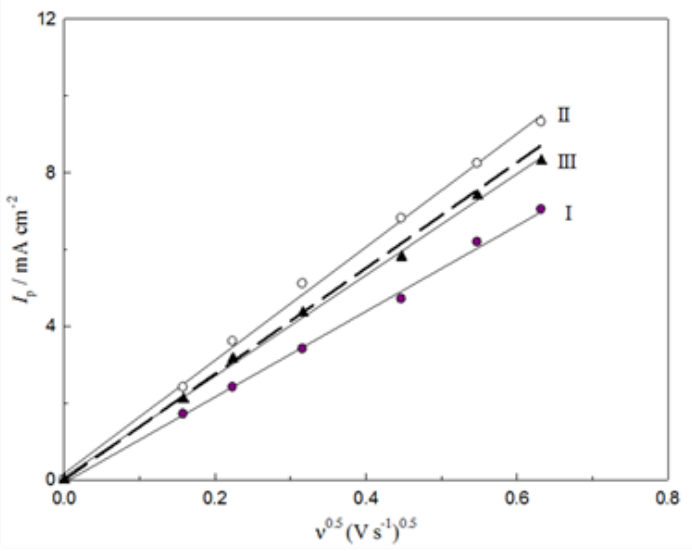

Figure 9 Plots of $I_{p}$ and $v 0.5$ for glucose oxidation on $\mathrm{GC} / \mathrm{NiO}_{\mathrm{x}}(\mathrm{I}), \mathrm{GC} \mathrm{OX}_{\mathrm{AC}} \mathrm{C}^{2}$ $\mathrm{NiO}_{x}$ (II) and $\mathrm{GC}_{\mathrm{Ox}-\mathrm{AL}} / \mathrm{NiO}_{\mathrm{x}}$ (III) from $0.5 \mathrm{M} \mathrm{NaOH}$ containing $10 \mathrm{mM}$ glucose. Theoretical plot of randles-sevick equation is also presented as the dashed line.a 
Enhancement of glucose oxidation either on $\mathrm{GC}_{\mathrm{OX}-\mathrm{AC}} / \mathrm{NiO}_{\mathrm{x}}$ or $\mathrm{GC}_{\text {OX-AL }} / \mathrm{NiO}_{x}$ compared to $\mathrm{GC} / \mathrm{NiO}_{x}$ may be discussed here. The enhancement may be attributed to the increase in the substrate (GC) surface area which gives rise to a better exposure of the $\mathrm{NiO}$ nanoparticles to glucose oxidation. As shown in Figure 2 the roughness and hence the surface area of $\mathrm{GC}_{\mathrm{OX}-\mathrm{AC}}$ is higher than that of $\mathrm{GC}_{\mathrm{OX}-\mathrm{AL}}$ As revealed from the SEM images in Figure 3, the size of the $\mathrm{NiO}_{x}$ nanoparticles on either $\mathrm{GC}_{\mathrm{OX}-\mathrm{AC}}$ or $\mathrm{GC}_{\mathrm{OX}-\mathrm{AL}}$ is lower than that deposited on the untreated GC. The decrease in the size of the $\mathrm{NiO}_{x}$ nanoparticles is accompanied by an increase in active sites concentration (Table 1) and hence an increase in the peak current of glucose oxidation. As evident from Figure $5 \&$ Table 1, there is an obvious enhancement of the redox $\mathrm{Ni}(\mathrm{OH})^{2} / \mathrm{NiOOH}$ couple as understood from the higher peak currents, reversibility and increase of the surface concentration of $\mathrm{Ni}$ active sites. The enhancement of glucose oxidation follows the enhancement of the $\mathrm{Ni}(\mathrm{OH})^{2} / \mathrm{NiOOH}$ couple.

According to literature, ${ }^{7,11}$ XPS study showed that graphitic, phenolic and carboxylic groups are the main functional groups upon anodic pretreatment of the GC. Higher adsorption of glucose on the more hydrophilic surface $\left(\mathrm{GCo}_{x}\right)$ may be offered by such an increase of $\mathrm{C}-\mathrm{O}$ functional groups. In another remark, while smaller particle size of $\mathrm{NiO}_{x}$ obtained on $\mathrm{GC}_{\mathrm{OX}-\mathrm{AC}}$ and higher surface area of $\mathrm{GC}_{\mathrm{OX}}$ ${ }_{A C}$ (higher roughness, Figure 2) compared to $\mathrm{GC}_{\mathrm{OX}-\mathrm{AL}}$ implement higher peak currents of glucose oxidation, the adsorbed -OH groups on the $\mathrm{GC}_{\text {OX-AL }}$ (coming from $\mathrm{NaOH}$ during anodic oxidation in the $\mathrm{NaOH})$ maybe the reason of the negative shift in both Ep and Eon set of glucose oxidation on the $\mathrm{GC}_{\mathrm{OX}-\mathrm{AL}} / \mathrm{NiO}_{\mathrm{x}}$. The role of adsorbed -OH group in catalyzing the electro oxidation of organic molecules is reported in literatures. ${ }^{52}$ Our results may be compared with literatures. The activity of our electrodes (either $\mathrm{GC}_{\mathrm{OX}-\mathrm{AL}}$ or $\mathrm{GC}_{\mathrm{OX}-\mathrm{AC}}$ ) expressed in $\mathrm{mA} \mathrm{cm}{ }^{-2}$ were compared with those in literatures at similar conditions. It was found that it is higher than $\mathrm{Ni}(\mathrm{OH})^{2}$ - Zeolite/CPE, ${ }^{53} \mathrm{Ni}(\mathrm{OH})^{2}$ chitosan/GC, ${ }^{54} \mathrm{GO}-\mathrm{NiO} / \mathrm{GC},{ }^{55} \mathrm{NiO} / \mathrm{GC},{ }^{6} \mathrm{Cu}-\mathrm{ZnO} / \mathrm{GC}^{56}$ and it was found to be closer to $\mathrm{CuO}_{\mathrm{\gamma}} / \mathrm{Cu}^{57}{ }^{57} \mathrm{NiO}_{\mathrm{x}}-\mathrm{MWCNT} / \mathrm{GC}^{58}$ and $\mathrm{Cu}-\mathrm{NPS} /$ GC. ${ }^{59}$ In the other the activity of the electrode in this work was found to be lower in performance than $\mathrm{Ni}-\mathrm{NPS} / \mathrm{GC}^{60}$ and $\mathrm{NiO}_{\mathrm{x}}$ (sol-gel)/ GC. ${ }^{26}$

\section{Conclusion}

The results showed significant impacts on the morphology (shape and size) of the $\mathrm{NiO}_{\mathrm{x}}$ nanoparticles when the substrate (GC electrode) was anodically pretreated at different anodic potentials and at different periods of time. The pretreatment of GC by anodic oxidation has its impact on the redox couple of $\mathrm{NiO}_{x}$, i.e., on the $\mathrm{Ni}(\mathrm{OH})^{2} / \mathrm{NiOOH}$. This was attributed to the increase in the GC surface area and in the concentration of C-O functional groups. Glucose electro oxidation is enhanced on either $\mathrm{GC}_{\mathrm{OX}-\mathrm{AC}} / \mathrm{NiO}_{\mathrm{x}}$ or $\mathrm{GC}_{\mathrm{OX}-\mathrm{AL}} / \mathrm{NiO}_{\mathrm{x}}$ compared to $\mathrm{GC} /$ $\mathrm{NiO}_{\mathrm{x}}$. While both $\mathrm{GC}_{\mathrm{OX}-\mathrm{AC}} / \mathrm{NiO}_{\mathrm{x}}$ and $\mathrm{GC}_{\mathrm{OX}-\mathrm{AL}} / \mathrm{NiO}_{\mathrm{x}}$ support high $I_{p}$ of glucose oxidation, $\mathrm{GC}_{\mathrm{OX}-\mathrm{AL}} / \mathrm{NiO}_{\mathrm{x}}$ shifts the $E_{p}$ and $E O_{n}$ set to more negative values. The above conclusions were generally discussed in the light of the obtained surface and electrochemical analysis. However, further work has to be done (e.g., XPS study) for further explanation of the above conclusions.

\section{Acknowledgements}

None.

\section{Conflict of interest}

The author declares no conflict of interest.

\section{References}

1. Kang C. Behavior of a macrocyclic cobalt complex adsorbed on an electro-oxidized glassy carbon electrode for the electrocatalytic reduction of $\mathrm{O}_{2}$. Journal of Electroanalytical Chemistry. 2001;498(1-2):51-57.

2. Schulz EN, Salinas DR, Garcia SG. Electrodeposition of rhodium onto a pre-treated glassy carbon surface. Electrochemistry Communications. 2010;12(4):583-586.

3. Maruyama J, Abe I. Influence of anodic oxidation of glassy carbon surface on voltammetric behavior of Nafion ${ }^{\circledR}$-coated glassy carbon electrodes. Electrochimica Acta. 2001;46(22):3381-3386.

4. Oztekina Y, Toka M, Bilici E, et al. Copper nanoparticle modified carbon electrode for determination of dopamine. Electrochim Acta. 2012;76:201-207.

5. Li F, Zhang B, Dong S, et al. A novel method of electrodepositing highly dispersed nano palladium particles on glassy carbon electrode. Electrochimica Acta. 1997;42(16):2563-2568.

6. Ghonim AM, Anadouli BE El, Saleh MM. Electrocatalytic glucose oxidation on electrochemically oxidized glassy carbon modified with nickel oxide nanoparticles. Electrochimica Acta. 2013;114:713-719.

7. Ling Zhao Q, Zhi L Zhang, Bao L, et al. Surface structure-related electrochemical behaviors of glassy carbon electrodes. Electrochem Commun. 2008;10(2):181-185.

8. Jovanovic VM, Terzic S, Tripkovic AV, et al. The effect of electrochemically treated glassy carbon on the activity of supported $\mathrm{Pt}$ catalyst in methanol oxidation. Electrochem Commun. 2004;6(12):1254 1258.

9. Jovanovic VM, Tripkovic D, Tripkovic A, et al. Oxidation of formic acid on platinum electrodeposited on polished and oxidized glassy carbon. Electrochem Commun. 2005;7(10):1039-1044.

10. Stevanovic S, Panic V, Tripkovic D, et al. Promoting effect of carbon functional groups in methanol oxidation on supported Pt catalyst. Electrochem Commun. 2009;11(1):18-21.

11. Saleh MM, Awad MI, Okajima T, et al. Characterization of oxidized reticulated vitreous carbon electrode for oxygen reduction reaction in acid solutions. Electrochim Acta. 2007;52(9):3095-3104.

12. Premkumer J, Khoo SB. Immobilization of ruthenium(II) bipyridyl complex at highly oxidized glassy carbon electrodes. Electrochemistry Communications. 2004;6(10):984-989.

13. Ilangovan G, Pillai KC. Unusual activation of glassy carbon electrodes for enhanced adsorption of monomeric molybdate(VI). J Electroanal Chem. 1997;431(1):11-14.

14. Engstrom RC. Electrochemical pretreatment of glassy carbon electrodes. Anal Chem. 1982;54(13):2310-2314.

15. Shi K, Keung Shiu K. Scanning tunneling microscopic and voltammetric studies of the surface structures of an electrochemically activated glassy carbon electrode. Anal Chem. 2002;74(4):879-885.

16. Dekanski A, Stevanovic J, Stevanovic R, et al. Glassy carbon electrodes: I. Characterization and electrochemical activation. Carbon. 2001;39(8):1195-1205.

17. Awad MI, Mahmoud M Saleh, Takeo Ohsaka. Oxygen reduction on rotating porous cylinder of modified reticulated vitreous carbon. J SolidState Electrochem. 2008;12(3):251-258.

18. Mao Sung Wu, Hung Ho Hsieh. Nickel oxide/hydroxide nanoplatelets synthesized by chemical precipitation for electrochemical capacitors. Electrochimica Acta. 2008;53(8):3427-3435. 
19. Dan Dan Zhao, Shu Juan Bao, Wen Jia Zhou, et al. Preparation of hexagonal nanoporous nickel hydroxide film and its application for electrochemical capacitor. Electrochemistry Communications. 2007;9(5):869-874.

20. Song Q, Tang Z, Guo H, et al. Structural characteristics of nickel hydroxide synthesized by a chemical precipitation route under different pH values. J Power Sources. 2002;112(2):428-434.

21. Jia D, Li F, Sheng L, et al. Synthesis and assembly of ultrathin film of $\mathrm{Ni}(\mathrm{OH})$, nanoparticles at gas/liquid interface, its high electrocatalytical oxidation toward bio-thiols and selective determination of cysteine. Electrochem Commun. 2011;13(10):1119-1122.

22. Li R, Wei Z, Huang A Yu T. Ultrasonic-assisted synthesis of Pd-Ni alloy catalysts supported on multi-walled carbon nanotubes for formic acid electrooxidation. Electrochim Acta . 2011;56(19):6860-6865.

23. Kiani MA, Abbasnia Tehrani M, Sayahi H. Reusable and robust high sensitive non-enzymatic glucose sensor based on $\mathrm{Ni}(\mathrm{OH})_{2}$, nanoparticles. Analytica Chimica Acta. 2017;839(11):26-33.

24. Hui S, Zhang J, Chen X, et al. Study of an amperometric glucose sensor based on Pd-Ni/SiNW electrode. Sens Act B: Chemical. 2011;155(2):592-597.

25. Garcia Miquel JL, Zhang Q, Allen SJ, et al. Nickel oxide sol-gel films from nickel diacetate for electrochromic applications. Thin Solid Films 2003;424(2):165-170.

26. Danial AS, Saleh MM, Salih SA, et al. Corrigendum to "On the synthesis of nickel oxide nanoparticles by sol-gel technique and its electrocatalytic oxidation of glucose". J Power Sources. 2015;293:101-108.

27. Luo Z, Yin S, Wang $\mathrm{K}$, et al. Synthesis of one-dimensional $\beta-\mathrm{Ni}(\mathrm{OH})$ nanostructure and their application as nonenzymatic glucose sensors. Mat Chem Phys. 2012;132(2-3):387-394.

28. Hutton LA, Vidotti M, Patel AN, et al. Electrodeposition of nickel hydroxide nanoparticles on boron-doped diamond electrodes for oxidative electrocatalysis. J Phys Chem C. 2010;115(5):1649-1658.

29. Miao Y, Ouyang L, Zhou S, et al. Electrocatalysis and electroanalysis of nickel, its oxides, hydroxides and oxyhydroxides toward small molecules. Biosensors and Bioelectronics. 2014;53:428-439

30. Singh RN, Singh A, Nintida $\mathrm{A}$, et al. Influence of the nature of conductive support on the electrocatalytic activity of electrodeposited $\mathrm{Ni}$ films towards methanol oxidation in $1 \mathrm{M} \mathrm{KOH}$. Int J Hydrogen Energy. 2008;33(23):6878-6885.

31. Spinner N, Mustain WE. Effect of nickel oxide synthesis conditions on its physical properties and electrocatalytic oxidation of methanol. Electrochimica Acta. 2011;56(16):5656-5666.

32. Nelson Torto, Ruzgas T, Gorton L. Electrochemical oxidation of monoand disaccharides at fresh as well as oxidized copper electrodes in alkaline media. Journal of Electroanalytical Chemistry. 1999;464(2):252-258.

33. Vidotti M, Cerri M, Carvalhal RF, et al. Nickel hydroxide electrodes as amperometric detectors for carbohydrates in flow injection analysis and liquid chromatography. Electroanal Chem. 2009;636(1-2):18-23.

34. Ganesh V, Maheswari DL, Berchmans S. Electrochemical behaviour of metal hexacyanoferrate converted to metal hydroxide films immobilized on indium tin oxide electrodes-Catalytic ability towards alcohol oxidation in alkaline medium. Electrochim Acta. 2011;56(3):1197-1207.

35. Pissinis DE, Sereno LE, Marioli J JM. Characterization of glucose electro-oxidation at $\mathrm{Ni}$ and $\mathrm{Ni}-\mathrm{Cr}$ alloy electrodes. Electroanal Chem. 2013;694:23-29.

36. Zhang Y, Xiao X, Sun Y, et al. Electrochemical deposition of nickel nanoparticles on reduced graphene oxide film for nonenzymatic glucose sensing. Electroanalysis. 2013;25(4):959-966.
37. Min Lu Li, Zhang L, Li Qu F, et al. A nano-Ni based ultrasensitive nonenzymatic electrochemical sensor for glucose: Enhancing sensitivity through a nanowire array strategy. Biosensors and Bioelectronics. 2009;25(1):218-223.

38. Ding R, Li X, Shi W, et al. Electrochimica Acta; 2016.

39. Wang X, Li W, Xiong D, et al. Bifunctional nickel phosphide nanocatalysts supported on carbon fiber paper for highly efficient and stable overall water splitting. Adv Funct Mater. 2016;26(23):4067-4077.

40. Abdel Aal A, Hassan HB, Abdel Rahim MA. Nanostructured Ni-P$\mathrm{TiO}_{2}$ composite coatings for electrocatalytic oxidation of small organic molecules. J Electroanal Chem. 2008;619-620:17-25.

41. Shao AF, Wang ZB, Chu ZB, et al. Evaluation of the performance of carbon supported Pt-Ru-Ni-P as anode catalyst for methanol electrooxidation. Fuel Cells. 2010;10(3):472-477.

42. Kucernak ARJ, Fahy KF, Sundaram VNN. Facile synthesis of palladium phosphide electrocatalysts and their activity for the hydrogen oxidation, hydrogen evolutions, oxygen reduction and formic acid oxidation reactions. Catalysis Today. 2016;262:48-56.

43. Tong YY, Gu CD, Zhang JL, et al. Urchin-like Ni-Co-P-O nanocomposite as novel methanol electro-oxidation materials in alkaline environment. Electrochim Acta. 2016;187:11-19.

44. Engstrom RC, Strasser VA. Characterization of electrochemically pretreated glassy carbon electrodes. Anal Chem. 1984;56(2):136-141.

45. Royce C Engstrom. Electrochemical pretreatment of glassy carbon electrodes. Anal Chem. 1982;54(13):2310-2314.

46. Schrebler Guzman RS, Vilche JR, Arvia AJ. Rate Processes Related to the Hydrated Nickel Hydroxide Electrode in Alkaline Solutions. J Electrochem Soc. 1978;125(10):1578-1587.

47. Giovanelli D, Lawrence NS, Jiang L, et al. Electrochemical determination of sulphide at nickel electrodes in alkaline media: a new electrochemica sensor. Sens Actuators B: Chem. 2003;88(3):320-328.

48. Refaei SM El, Saleh MM, Awad MI. Enhanced glucose electrooxidation at a binary catalyst of manganese and nickel oxides modified glassy carbon electrode. J Power Sources. 2013;223:125-128.

49. Fleischmann M, Korinek K, x Pletcher K. The oxidation of organic compounds at a nickel anode in alkaline solution. J Electroanal Chem Int Electrochem. 1971;31(1):39-49.

50. Bard AJ, Faulkner LR. Electrochemical methods: fundamentals and applications. New York, USA: Wiley; 1980. 864 p.

51. Gao F, Guo S, Ma H, et al. Nickel oxide microfibers immobilized onto electrode by electrospinning and calcination for nonenzymatic glucose sensor and effect of calcination temperature on the performance. Biosens Bioelectron. 2011;26(5):2756-2760.

52. Casella IG, Guascito MR, Sannazzaro MG. Voltammetric and XPS investigations of nickel hydroxide electrochemically dispersed on gold surface electrodes. J Electroanal Chem. 1999;462(2):202-210.

53. Darzi SKH, Rahimnejad M, Mirzababaei SN. Electrocatalytic oxidation of glucose onto carbon paste electrode modified with nickel hydroxide decorated NaA nanozeolite. Microchemical Journal. 20156;128:7-17.

54. Ciszewski A, Stepnia I. Nanoparticles of $\mathrm{Ni}(\mathrm{OH})_{2}$ embedded in chitosan membrane as electrocatalyst for non-enzymatic oxidation of glucose Electrochim Acta. 2013;111:185-191.

55. Zhang Y, Wang Y, Jia J, et al. Nonenzymatic glucose sensor based on graphene oxide and electrospun $\mathrm{NiO}$ nanofibers. Sensors and Actuators B. 2012;171-172:580-587. 
56. Ashok Kumar S, Hui Wen Cheng, Shen Ming Chen, et al. Preparation and characterization of copper nanoparticles/zinc oxide composite modified electrode and its application to glucose sensing. Materials Science and Engineering. 2010;C30:86-91.

57. Babu TGS, Ramachandran T. Development of highly sensitive nonenzymatic sensor for the selective determination of glucose and fabrication of a working model. Electrochim Acta. 2010;55(5):1612 1618 .
58. Kullyakool S, Danvirutai C, Siriwong K, et al. Therm Anal Calorim. 2014;115:1497-1507.

59. Zhang Y, Su L, Manuzzi D, et al. Ultrasensitive and selective nonenzymatic glucose detection using copper nanowires. Biosensors and Bioelectronics. 2012;31(1):426-432.

60. Danaee I, Jafarian M, Forouzandeh F, et al. Impedance spectroscopy analysis of glucose electro-oxidation on Ni-modified glassy carbon electrode. Electrochimica Acta. 2008;53(22):6602-6609. 